\title{
Digital Development of Slovenian Wood Industry
}

\section{Digitalni razvoj slovenske drvne industrije}

\author{
Original scientific paper • Izvorni znanstveni rad \\ Received-prispjelo: 20. 10. 2019. \\ Accepted-prihvaćeno: 28. 4. 2020. \\ UDK: $630 * 7$ \\ https://doi.org/10.5552/drvind.2020.1961
}

\author{
(C) 2020 by the author(s). \\ Licensee Faculty of Forestry, University of Zagreb. \\ This article is an open access article distributed \\ under the terms and conditions of the \\ Creative Commons Attribution (CC BY 4.0) license.
}

\begin{abstract}
The research examined the digital development of the Slovenian wood industry, especially the implementation of the concept of Industry 4.0 into practice. Within this, the implementation of specific technological pillars was studied, with the emphasis on smart factories and smart, innovative products. In the empirical part of the research, we prepared a survey and interviewed selected managers and entrepreneurs. We compared answers regarding sub-sectors, the size of the companies and the level of digitalization. The general results show that around half of the surveyed companies are already implementing the Industry 4.0 concept into their businesses, while the rest are beginners when speaking about digitalization. The biggest obstacles to the implementation of the concept are the high investments in equipment and the lack of financial support from the state. The lack of digital competencies, which is especially prevalent among older workers, is another major barrier that businesses face. Only $30 \%$ of the surveyed companies are engaged in the production of smart products. We can conclude that digitalization in the Slovenian wood industry is still at a relatively low level, but with the latest strategic orientations at both the state and business level, this situation will certainly improve in the near future.
\end{abstract}

Keywords: Digitalization; Industry 4.0; Internet of Things; Wood-industry; Slovenia

SAŽETAK・U radu je predočeno istraživanje digitalnog razvoja slovenske drvne industrije, posebice istraživanje primjene koncepta Industrija 4.0 u praksi. Unutar toga proučavana je primjena specifičnih tehnoloških stupova s naglaskom na pametne tvornice i pametne, inovativne proizvode. U empirijskom dijelu istraživanja pripremili smo anketu i intervjuirali odabrane menadžere i poduzetnike. Usporedili smo odgovore koji se odnose na podsektore, veličinu poduzeća i razinu digitalizacije. Opći rezultati pokazuju da približno polovica anketiranih tvrtki u poslovanju već primjenjuje koncept Industrija 4.0, dok su ostale tvrtke početnici u digitalizaciji. Najveće su prepreke provedbi koncepta velika ulaganja u opremu i izostanak državne financijske potpore. Nedostatak digitalnih kompetencija, koji je osobito vidljiv među starijim radnicima, dodatna je velika prepreka s kojom se tvrtke suočavaju. Samo 30 \% anketiranih tvrtki bavi se proizvodnjom pametnih proizvoda. Može se zaključiti da je digitalizacija u slovenskoj drvnoj industriji još uvijek na relativno niskoj razini, ali s najnovijim strateškim orijentacijama i na državnoj i na poslovnoj razini ta će se situacija u skoroj budućnosti sigurno poboljšati.

Ključne riječi: digitalizacija; Industrija 4.0; internet stvari; drvna industrija; Slovenija

\section{INTRODUCTION 1. UVOD}

Digital development is an important aspect of the development of society as a whole, and of all (business) entities operating within them. Globalization and the rapid development of information and communication technologies (ICT) are causing major changes in modern societies. The so-called information society, also called the knowledge society or even digital society, is establishing what Keidanren (2016) calls a smart society. The development of a digital society provides

\footnotetext{
${ }^{1}$ Author is assistant professor at Department of Wood Science and Technology, Biotechnical Faculty, University of Ljubljana, Ljubljana, Slovenia. ${ }^{2}$ Author is assistant professor at Department of Forestry and Renewable Forest Resources, Biotechnical Faculty, University of Ljubljana, Ljubljana, Slovenia.
} 
many opportunities for progress, but also many challenges. A digital single market in Europe, one of the top ten priorities of the European Commission, would create the right environment, both formally and technologically, for the effective development of digital society at the European level and in all Member States (European Commission, 2016).

Research shows that the state of digitization of European society is poor, as half of the EU population still lacks basic digital literacy and competencies (European Commission, 2019). This and major technological advances in the field of digitalization require concrete actions at the level of economic policies. At the EU level, one of the most important actions in the digitization of society is the Smart Specialization Strategy (S3) (European Commission, 2018). In Slovenia, the implementation of this concept is an important part of the country's economic policy, which is also reflected in the smart specialization strategy platform for directing development investments in areas where Slovenia has a critical mass of capacities, knowledge, and competencies, and where innovation potential is highly expressed (Republic of Slovenia, 2019).

As an important part of industrial development, significant changes are expected in the whole economy and each company in the field of digitalization, which is one of the Key Enabling Technologies at the EU level (Commission of the European Communities, 2009). Despite the high importance of digitization and in spite of the economic growth of Slovenia in recent years (Kmet Zupančič, 2019), as many as $82 \%$ of Slovenian companies have a low digital index (which measures the intensity of the use of ICT in doing business), and within manufacturing companies the situation is even worse (Zupan, 2018; Statistical Office, 2018).

The concept of "Industry 4.0" symbolizes the beginning of the fourth industrial revolution (Lasi et al., 2014). It was presented as a strategic initiative to increase German competitiveness in the manufacturing industry, with the aim of transforming industrial production by digitizing and harnessing the potential of new technologies (Herakovich, 2016). It represents the modern technological trends of automation and creates the so-called cyber-physical systems, while technologically it is reflected in the Internet of Things (IoT) and cloud computing solutions (Xu et al., 2018). Industry 4.0 is changing the way companies operate, and requires major investments in new technologies if they are to remain competitive in the market. New strategies and advantages are required to face international competitors, which, among other, include new business models, improvement of productivity, innovations and cooperation in terms of technology, outsourcing and supply chain (Paluš et al., 2015). In case of environmentally sensitive markets, the competitiveness is influenced by factors related to the origin of wood material from sustainable and renewable sources (Paluš et al. 2019). Companies need to decide how and where to invest in new technologies, and which ones can best meet their needs. Without a full understanding of the changes and opportunities that Industry 4.0 can provide, companies are at risk of great loss (Cotteleer and Sniderman, 2017). An important notion that we are facing in Industry 4.0, and closely related to it, is the IoT. This is reflected at the level of smart cities, smart factories, smart homes, and smart products. However, with the improvement of wireless communications, smartphones and sensor network technologies, more and more networked things and smart devices are being integrated into IoT (Xu et al., 2014). Within the technological pillars and trends of the concept of Industry 4.0, it is expected that blockchain, digital twins, quantum computing, augmented analytics and artificial intelligence will drive disruption and new business models (Panetta, 2018).

The term "smart factory" is not yet dominant, as there are several other terms that are also used for the same idea, such as the u-factory or ubiquitous factory, the Factory of Things, the real-time factory, and the intelligent factory of the future (Hozdić, 2015). Movrin (2017) argues that a smart factory connects the human, product, process, and business to a holistic system and contains the following components: smart products, smart equipment, smart people, smart conceptualized processes and smart management. In this context, two important terms appear, namely smart products and smart people. Smart products are able to perform calculations, store data and communicate with the environment. Not only do these products provide their identity, but they also describe their characteristics, status, and history, and are able to provide information about their life cycle (Schmidt et al., 2015). Even in the timber industry, this concept is not entirely new. For example, IKEA has been involved in the manufacture of various pieces of smart furniture and smart homes for several years. Besides wardrobes with smart lighting and other single smart furniture solutions, Ikea is launching a new robotic furniture system called Rognan for people who live in small spaces; the large storage unit, controlled by a touchpad, can slide across a room to divide it into two living spaces, and contains a bed, desk, and a couch. (Lee, 2019). Some Slovenian wood industry companies have already started developing intelligent furniture (Alples, 2016). Digital competencies, which relate to the confident and critical use of a full range of digital information and communication technologies and solve underlying problems, are essential in the context of "smart people" (Carretero Gomez et al, 2017). However, the digital literacy of employees in Slovenian companies is at a relatively low level, so companies will in the future be forced to provide the training needed to acquire the digital competencies required by certain jobs (Kropivšek, 2018).

The research was focused on an examination of the understanding of the concept of Industry 4.0 and its implementation in the Slovenian wood industry. We also studied the implementation of specific technological pillars into practice, with the emphasis on smart factories and smart, innovative products. The objective of the research was to measure the degree of digitalization, to define the challenges and obstacles that companies encountered before or during the digitalization process and to measure the impact of information and 
communication technologies on business in the next three years. Beside this, the importance of digitization activities in the strategic plans of companies was established, and the share of revenue that companies intend to invest in digitization over the next years was measured. Within this, one of the goals of the research was to calculate the correlation between the level of digitalization and the share of revenue that companies intend to invest in it over the next three years. We also intended to evaluate the "factory of the future" elements that companies already use or plan to use at their factory in the next three years. Finally, we were interested in whether there are differences between companies from different sub-sectors and between companies of different sizes.

\section{METHODS}

\section{METODE}

In the empirical part of the research, we prepared a survey and interviewed selected managers and entrepreneurs. The questionnaire included topics like the challenges of digitalization, strategic directions, digital competencies, data analytics, smart products, and smart factories. The questionnaire consisted of 21 questions; three of these were demographic and most of the others asked for Likert-type scale responses. More in detail, the questions in the questionnaire were about the Industry 4.0 potential, the degree of digitalization, challenges and obstacles that companies encountered before or during the digitalization process, impact of information and communication technologies on business in the next three years, the importance of digitization activities in the strategic plans of companies for their investments in the next three years, the share of revenue that companies intend to invest in digitization over the next three years and the "factory of the future" elements that companies use in their factory or plan to use in the next three years. The survey process took place from $18^{\text {th }}$ of November 2018 to $25^{\text {th }}$ of February 2019 in digital format on the $1 \mathrm{ka}$ web portal (1ka, 2019). The target population of the survey was as follows: companies operating in sub-sectors C16 (wood processing) and C31 (manufacture of furniture) in Slovenia (NACE, 2019), members of the Chamber of Commerce and Industry of Slovenia and the Chamber of Craft and Small Business of Slovenia. Invitations to complete the questionnaire were sent by those two institutions to their members. Since the exact number of members and their addresses are a business secret that was not disclosed to us, we only assume that the population size was about 1000 companies. We received answers from 131 companies. Forty-one companies answered only demographic questions, 44 companies partly completed the questionnaire (they answered the first few questions), and the rest 46 companies answered all the questions in the survey. The statistical software SPSS 25.0 was used for data analysis, and the results are presented in this work. We presented the results of the Likert-scale questions using a diverging stacked bar chart, which is especially suitable for the presentation of this type of data (Robbins and Heiberger, 2011). The Fish- er's Exact Test was used to compare the results regarding sub-sectors and the size of the companies. Spearman's rank correlation coefficient was used as a nonparametric measure of dependence between the size of the companies and the challenges of digitalization, the level of digitalization and the production of smart products, and the level of digitalization and the share of revenue that companies intend to invest in it over the next three years.

In the second part of the study, we interviewed managers and entrepreneurs of three wood industry companies of different sizes (two of them were midsize and one of them small company) with a long tradition and a clear orientation into the future. The interviews were conducted in July 2019.

\section{RESULTS}

\section{REZULTATI}

Among the companies that participated in the survey and answered all the questions (46 companies), more than half (54\%) were micro size, $30 \%$ were small and $16 \%$ mid-size / big companies. The proportions were also similar for the first few questions from the survey that more respondents answered. The mix of companies by size in the survey is comparable to that seen in the Slovenian wood industry, where micro and small companies prevail (Kropivšek et al, 2019). The proportions of respondent companies operating in sub-sectors C16 and C31 are similar (about $45 \%$ ), while $10 \%$ of companies selected "Other" as their main activity (carpentry, roofing, sales, installation of furniture, etc).

The question about the degree of digitalization was answered by 90 companies; 54 were micro companies, 27 small and nine mid-size or big. The red colour in Figure 1 indicates companies that are not prepared or are just preparing for digitalization. Half of the companies $(50 \%)$ are complete beginners in the introduction of the concept of Industry 4.0 into their business. One-quarter of companies (23\%) know about digitalization and are preparing to launch it. Only one small company has a clear digitalization plan. The blue colour presents companies that have already started the process of digitalization. Eight percent of the companies have started their first digitalization activities, 17 $\%$ of companies are already digitized to some extent, and only one company is fully digitized. Although the term Industry 4.0 has been known since 2011, implementation of the concept in Slovenian wood companies is quite low. We can conclude that the level of digitalization is the lowest in micro companies, followed by small companies, while as many as $67 \%$ of mid-size and big companies are digitalized to some extent. The level of digitalization differs significantly among the different sizes of companies ( $p=0.026$, Fisher exact test). The level of digitalization differs significantly among sub-sectors as well ( $p=0.037$, Fisher exact test), especially between $\mathrm{C} 31$ and other, where C31 is better, while between $\mathrm{C} 31$ and $\mathrm{C} 16$ sub-sectors there are no differences. 


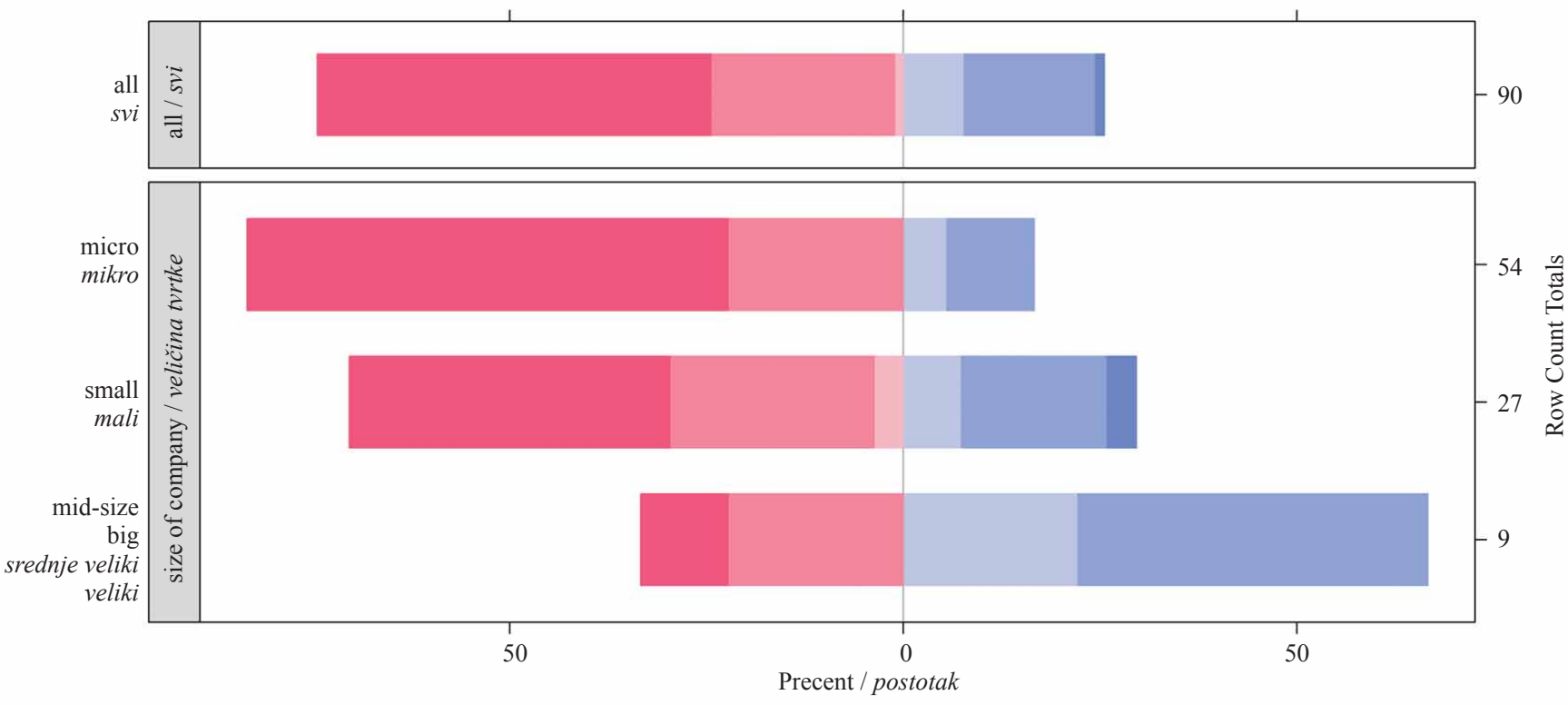

We are complete beginners. Potpuni smo početnici. We know what digitalization means and we are preparing for the launch. We have a clear plan for digitalization. / Imamo jasan plan uvođenja digitalizacije. We have already started the first digitalization activities. Već smo započeli s prvim aktivnostima uvođenja digitalizacije. Our company has already been digitalized to some extent. Naša je tvrtka u određenoj mjeri već digitalizirana.

Our company is fully digitalized. / Naša je tvrtka potpuno digitalizirana.

Figure 1 Degree of digitalization, $n=90$

Slika 1. Stupanj digitalizacije tvrtki, $n=90$ Insufficient assistance from the state
nedostatna (premalena) pomoć od države visoki troškovi održavanja opreme High investment in the development and introduction of digitalization visoke investicije u razvoj i uvođenje digitalizacije

Greater potential for abuse (e.g. data theft, identity theft, etc.) veća mogućnost zlouporabe (npr. krađa podataka, krađa identiteta $i$ dr.)

Low self-criticism in planning and implementing change (pre)niska samokritičnost pri planiranju i uvođenju promjena

Reinforcement of analytical potential (data collection and analysis) osnaživanje analitičkih potencijala (prikupljanje $i$ analiza podataka) Ensuring systematic digitalization osiguravanje sistematičnosti digitalizacije Ensuring the agility (and learness) of the process osiguravanje agilnosti (i vitkosti) procesa Lack of digital competencies pomanjkanje digitalnih kompetencije Introducing new ways of learning / developing competencies uvođenje novih načina učenja / razvoja kompetencija Resistance of business partners in the value chain otpor poslovnih partnera u lancu vrijednost Fear of change strah od promjen

Slow development of digital competencies spori razvoj digitalnih kompetencija

The negative health effects of using ICT negativni učinci uporabe ICT-a na zdravlje

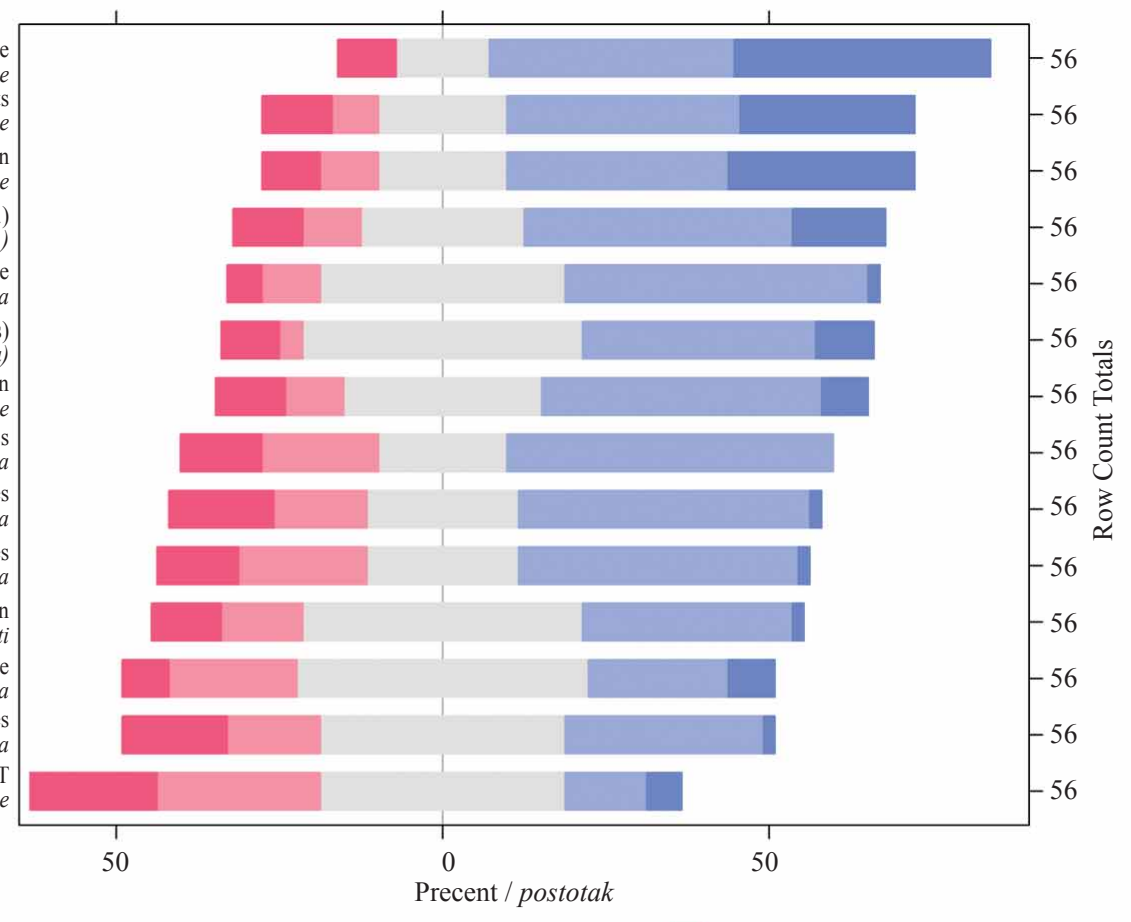

Challenge is not present /nema izazova

Represents a smaller challenge / predstavlja manji izazov

Neither a big nor small challenge / ni veliki niti mali izazov

Represents a bigger challenge / predstavlja veći izazov

Represents a huge challenge / predstavlja veliki izazov

Figure 2 Challenges and obstacles that companies encountered before or during the digitalization process, $n=56$

Slika 2. Izazovi i prepreke s kojima se tvrtke susreću prije i tijekom procesa digitalizacije, $n=56$ 
The biggest challenge in the digitalization process is Insufficient assistance from the state, with $78 \%$ of the surveyed companies considering it as a big or a very big challenge. High hardware maintenance costs, High investments in the development and introduction of digitalization and a Greater potential for abuse also represent significant obstacles. According to the respondents, the least important challenge is the negative health effects of using ICT, because $20 \%$ of respondents do not face this problem at all, and $26 \%$ believe that it is only a small obstacle for their company. It is interesting that the Resistance of business partners in the value chain, Fear of change and Slow development of digital competencies appear to be relatively small challenges for the companies. On average, small companies face the biggest challenges with regard to digitalization, while for mid-size and big companies the problems are smaller. Statistically significant differences among different sizes of companies were found only for the challenge of a Greater potential for abuse ( $p=0.002$, Fisher exact test). The correlation between the size of the companies and the challenge Greater potential for abuse was negative (Spearman correlation coefficient $=0.350, p=0.008)$. The size of the various challenges and obstacles does not differ significantly among sub-sectors.

Figure 3 shows that, according to the respondents, cloud computing (37\%), smart applications and analytics $(30 \%)$ and conversational platforms $(28 \%)$ currently have the most impact on their business. In contrast, artificial intelligence (8\%), digital twins (8\%), immersive experience (10\%) and blockchain (12\%), have the least impact on the business. In addition to the technologies that already have an impact, most respondents stated that smart things, event-driven computing and artificial intelligence will have a significant impact in the future. However, a large proportion of companies $(41 \%)$ believe that artificial intelligence does not and will not affect their business in the future. Similarly, a high proportion of companies believe that their business will not be affected by immersive experience $(31 \%)$ and blockchain $(31 \%)$. Cloud computing was expected to have or will have an impact on most companies in the future, as data storage offers security and makes it easier to share data with others. Also, the use of smart applications and conversational platforms is almost inevitable in today's world. According to the respondents, smart things do not have a big impact on their business yet, but they expect this to grow in the future. This is understandable, since smart things, factories and cities cause changes in the environment and market, and are a trend that is changing both society and business. Almost half of the companies believe that artificial intelligence does not and will not affect their business in the future. One of the important reasons for this opinion is the very high investment required to implement artificial intelligence.

A third of the surveyed companies (30\%) are engaged in the production of smart products. Most of them (23\%) manufacture other furniture, $14 \%$ manufacture chairs and tables, $11 \%$ interior constructions and cabinets, $9 \%$ exterior constructions and artistic products,

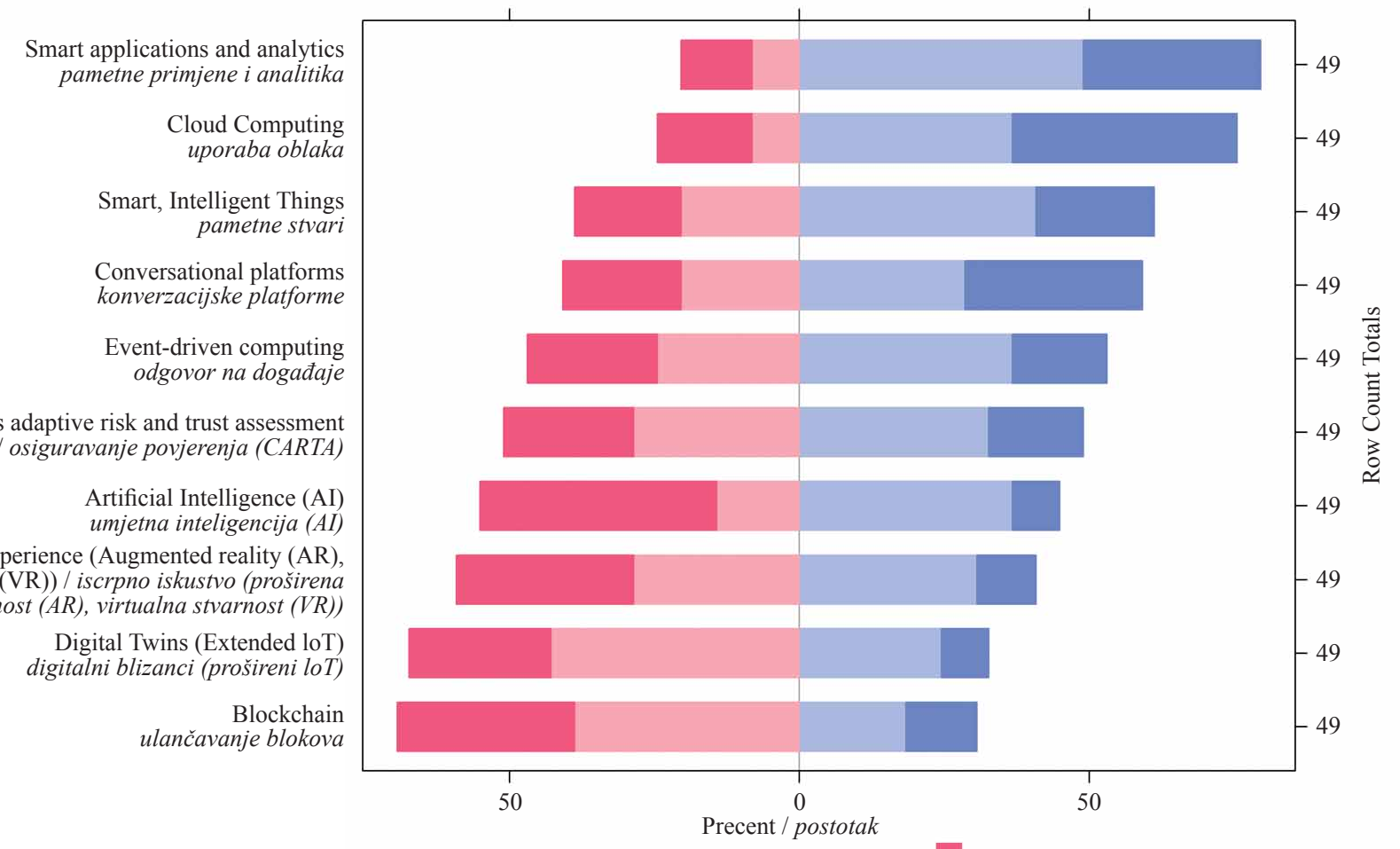

Do not and will not affect / ne utječe i neće utjecati

Have no opinion / nema mišljenje

Will affect / utjecat će

Already affects / već utječe

Figure 3 Impact of information and communication technologies on business in the next three years, $n=49$

Slika 3. Utjecaj informacijsko-komunikacijskih tehnologija na poslovanje u sljedeće tri godine, $n=49$ 


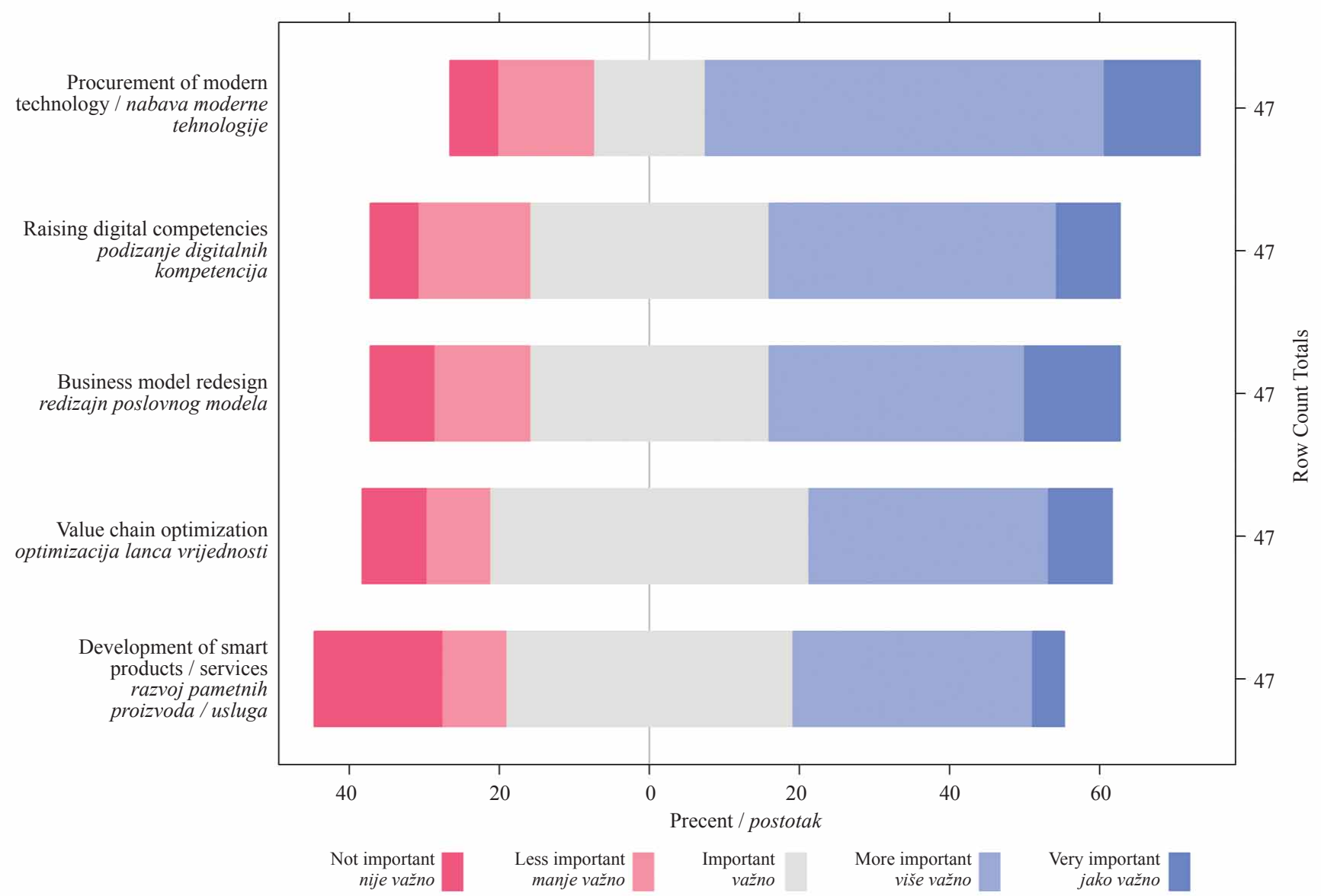

Figure 4 Importance of digitalization activities in strategic plans of companies for their investments in the next three years, $n=47$ Slika 4. Važnost digitalizacijskih aktivnosti u strateškim planovima poduzeća za njihova ulaganja tijekom sljedeće tri godine, $n=47$

while $3 \%$ produce packaging, wooden fancy goods, sports tools and wooden toys. The results are as expected, as smart furniture has only become a trend in the last few years. In the next few years the manufacturing of smart products is expected to grow, because the primary goal of smart products is not just to make life easier for their users, but also to send feedback to manufacturers, enabling them to continually improve and upgrade their products. The differences in the proportions of companies that manufacture smart products among the various sizes of companies and sub-sectors are not significant. We were interested in whether those companies on a higher level of digitalization manufacture smart products more often, but the correlation is insignificant (Spearman correlation coefficient $=0.147, p=0.135$ ).

Figure 4 shows that, according to the respondents, the most important digitalization activity in their strategic plans is the Procurement of modern technology, because $65 \%$ of respondents estimate that this is important or very important for their investments over the next three years. Raising digital competencies and Business model redesign are the second most important, followed by Value chain optimization. According to the respondents, the Development of smart products or services is the least important activity.

Most of the surveyed companies (89\%) (Figure 5) intend to invest a certain share of revenues in the digitization of their business in the next three years. Eleven percent of companies do not intend to invest in digitalization, while $48 \%$ intend to invest up to $2 \%, 30 \%$ of companies up to $5 \%$, and $11 \%$ of companies above $5 \%$. The differences between the sizes of companies and subsectors are not significant. Figure 6 shows the correlation between the rate of digitization and the share of revenue that companies intend to invest in this over the next three years. The numbers in the circles and the sizes of circles indicate how many companies fall into a given category. The results show that the correlation is positive, and that more digitalized companies intend to invest more in digitization in the future. The positive correlation between the level of the digitalization and the share of revenue that companies intend to invest in digitization over the next three years is also confirmed by the Spearman correlation coefficient $(0.502, p<0.001)$.

Figure 7 shows that the companies in Slovenia rarely use the elements of the factories of the future. However, more use is anticipated within the next few years. Twenty-eight percent of the surveyed companies already use advanced materials, and $15 \%$ use advanced sensors. The share of companies that use advanced sensors differs significantly among different sizes of companies ( $p=0.014$, Fisher exact test). Among mid-sized / big companies, almost half indicate that they use advanced sensors. None of the companies use smart plasma systems, and only $7 \%$ use $3 \mathrm{D}$ printing. The difference in the use of 3D printing among different sizes of companies is significant ( $p=0.021$, Fisher exact test). Among the other elements of the factory of the future mentioned in the survey, only intelligent guidance systems $(11 \%)$ are used by more than $10 \%$ of the compa- 


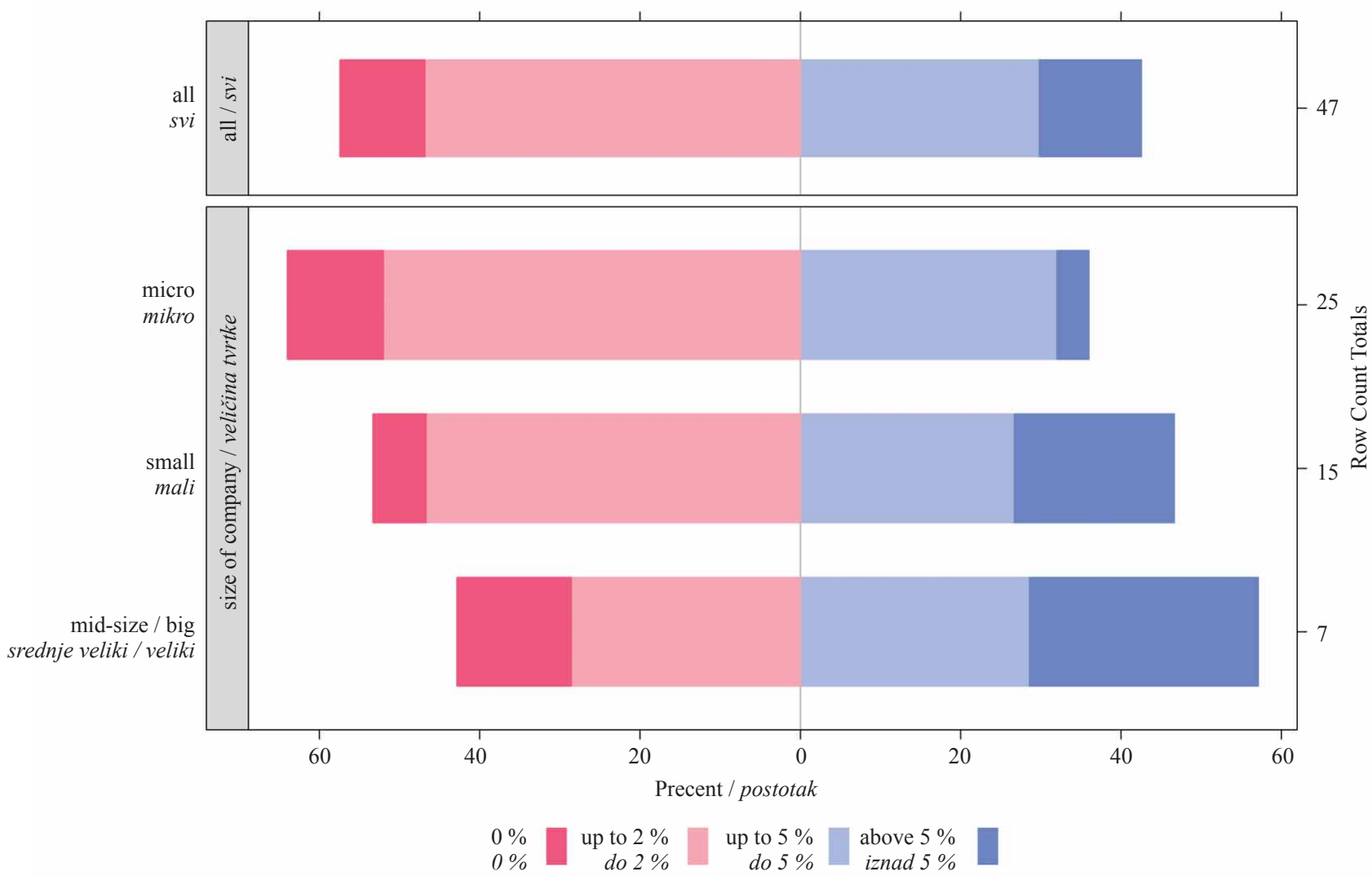

Figure 5 Share of revenue that companies intend to invest in digitization over the next three years, $n=47$

Slika 5. Udio prihoda koji tvrtke namjeravaju uložiti u digitalizaciju tijekom sljedeće tri godine, $n=47$

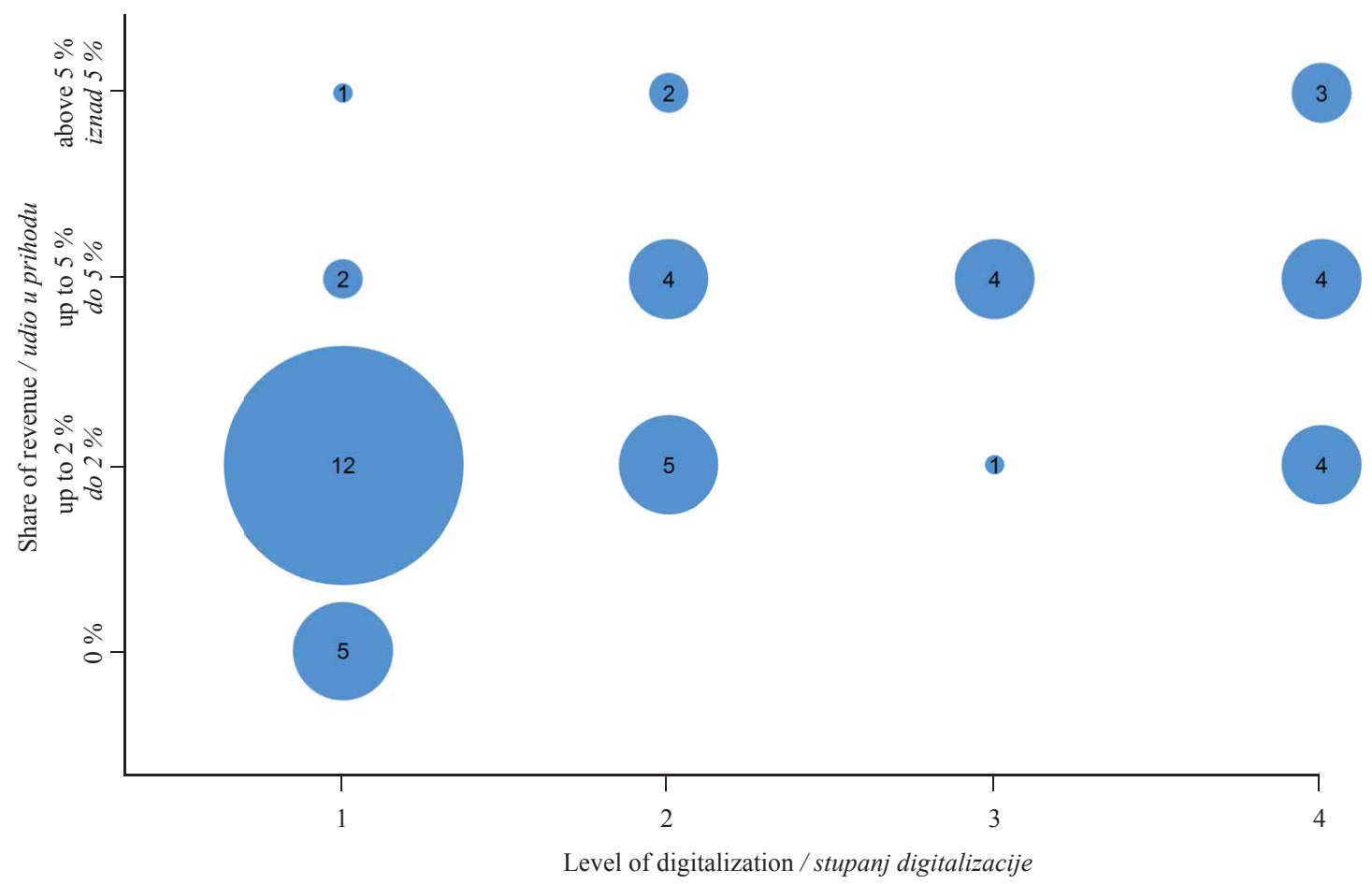

Figure 6 Correlation between the level of digitalization and share of revenue that companies intend to invest in it over the next three years, $n=47$. Numbers in circles represent the number of companies in the groups (Legend of the $x$-axis: $1-$ We are complete beginners, 2 - We know what digitalization means and we are preparing for the launch, 3 - We have already started the first digitalization activities, 4 - Our company has already been digitalized to some extent)

Slika 6. Korelacija razine digitalizacije i udjela prihoda koji tvrtke namjeravaju uložiti u digitalizaciju tijekom sljedeće tri godine, $n=47$; brojevi u krugovima označavaju broj tvrtki u skupinama (legenda osi $x$ : 1 - potpuni smo početnici, 2 - znamo što znači digitalizacija i pripremamo se za njezino uvođenje, 3 - već smo započeli prve digitalizacijske aktivnosti, 4 - naša je tvrtka već donekle digitalizirana) 


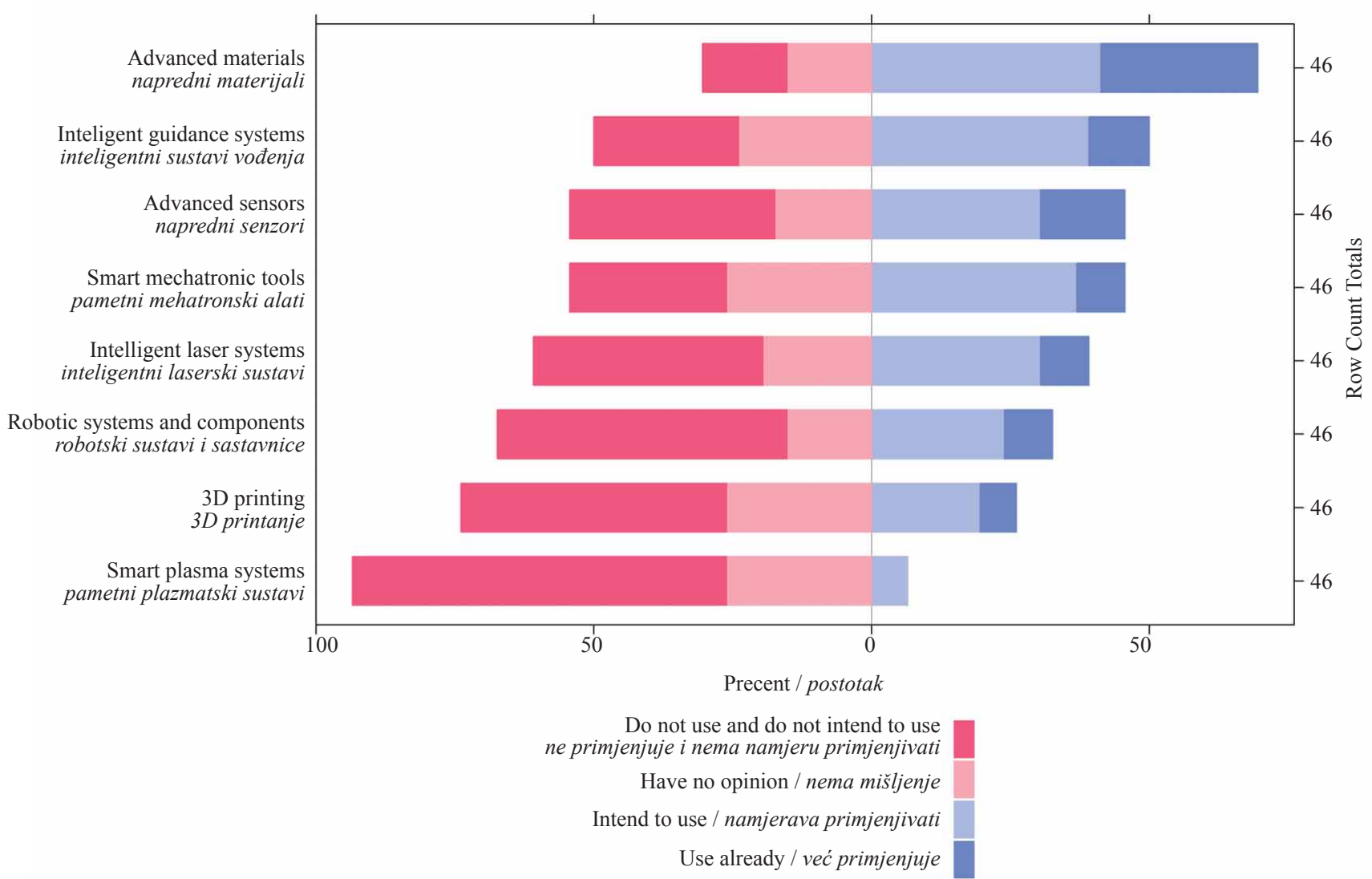

Figure 7 The "factory of the future" elements that companies use at their factory or plan to use in the next three years, $n=46$ Slika 7. Elementi „tvornice budućnosti“ što ih tvrtke primjenjuju u svojoj tvornici ili ih planiraju uvesti tijekom sljedeće tri godine, $n=46$

nies. Robotic systems and components are only used by micro and mid-size / big companies, and not by small companies, which indicates that the difference among different sizes of companies is statistically significant ( $p=0.029$, Fisher exact test). Advanced materials (41\%), intelligent guidance systems (39\%) and smart mechatronic tools $(37 \%)$ are elements of the factory of future that are currently not used but a large number of companies intend to use them in the next three years.

\section{DISCUSSION \\ 4. RASPRAVA}

Digitalization is changing the way companies do business and is closely linked to investments in modern (digital) technology, its development, and use. This is also strongly linked to the development of the competencies of employees who use and develop these technologies. This is especially true for technology-based companies, which include wood-industry (manufacturing) companies operating in the $\mathrm{C} 16$ and $\mathrm{C} 31 \mathrm{sub}-\mathrm{sec}$ tors. More than $80 \%$ of the sample of companies surveyed in this research were micro and small enterprises, and this proportion is representative of the wood industry in Slovenia. Since digitalization requires significant investment on the one hand and demands great flexibility to meet this adaptation/change on the other, we were interested in whether there are any differences between different sizes of companies in this context.

Half of the surveyed companies are already implementing the concept of Industry 4.0, as a fundamental concept of digitalization of manufacturing companies, into their businesses, while the rest are beginners in terms of digitalization. Comparing the rate of digitization by the size of companies, we found out that the worst situation is among micro-companies, while it is better in mid-size and large companies, where up to twothirds of enterprises are already digitized. This confirms that the size of enterprises affects the degree of digitization. The correlation between business efficiency and performance, where C16 is better than C31 (Kropivšek et al., 2019; Kropivšek et al., 2017), and the degree of digitization could not be confirmed. However, we have confirmed that more successful companies are more aware of the importance of digitalization for the success of their current and, above all, future business, and therefore invest more in it. There is a positive correlation between the degree of digitalization and share of revenue that companies intend to invest in it over the next three years, which means that the more digitalized companies intend to invest even more in this in the future than the less developed ones. This is the result of a higher level of awareness of the importance of digitalization in ensuring the success of the business in the digital age, and earlier positive experiences of the results of digitization. This was also confirmed by the interviewees.

The biggest obstacles to the implementation of the concept of digitalization in business are high investments for the equipment and lack of financial support from the state. On average, small businesses face the biggest challenges, while medium and large companies face smaller challenges in the digitalization process. As 
expected, for smaller companies the amount of any investment and high maintenance costs are far more important than for larger ones, but, on the other hand, it is surprising that practically all challenges related to people (resistance to change, lack of competencies, etc.) are seen as less problematic. There were no significant differences in this regard among companies of different sizes. One of the major challenges is the lack of digital competencies among older workers, which was especially highlighted in the interviews. This, as well as an awareness that new knowledge and digital competencies will be necessary for the further development of companies, led the surveyed companies to see as very important an increase in digital competencies of employees in the strategic plans of companies for their investments in the next three years. This is especially true for mediumsized and large companies, which have a greater proportion of older employees, and these are more aware of the importance of digitalization to business success. While implementing the concept of Industry 4.0, the surveyed companies ranked as the most important the following digital competencies (from the DigComp model (Carretero Gomez et al., 2017)): information literacy, understanding and ensuring digital security, and communication/collaboration using modern ICT. These findings are in line with the fundamental guidelines for the development of an information society in Europe (European Commission, 2016).

For the surveyed companies, investing in modern, digital technology and developing digitalized business models, in addition to raising digital competencies, represent the most important activities in their strategic investment plans. In the context of investing in ICT, companies evaluate as the most important investing in cloud computing and conversation platforms, smart app and smart things development, as they are seen as already influencing, or soon will influence, the operation of the companies in the near future. In particular, this refers to investing in smart things (IoT), which does not yet have a major impact on the operations of the surveyed companies but is becoming increasingly important globally. Companies expect the IoT to have a major impact on their business performance in the future, notably the development of smart products and the implementation of (more) elements of a smart factory into their operations. We found that only about a third of the surveyed companies are currently engaged in the development and manufacture of smart products, which is rather low considering their importance. The more digitalized companies are making smart products more often, but the correlation is insignificant. We also looked at the implementation of smart factory elements, which are applied (on average) in less than $15 \%$ of the surveyed companies. Within the elements of smart factories, advanced materials and sensor technologies stand out in particular. Among other elements of the factory of the future, only intelligent management systems are used by more than 10 $\%$ of companies. Advanced materials, intelligent guidance systems, and smart mechatronic tools are also elements that are planned to be used by a large number of surveyed companies over the next three years, but are not currently in use.

As part of the Smart Specialization Strategy projects that have been ongoing in Slovenia and Europe since 2015 (STA, 2015), companies see the greatest potential in creating international connections and globalization, followed by improving (digital) competencies, developing new (smart) materials and products, and encouraging investment in technology, including digital infrastructure. In all these elements, companies see great potential. Considering the number of projects carried out under the Smart Specialization Strategy of Slovenia and strategic research and innovation partnerships (SRIP) (Republic of Slovenia, 2019), within which many wood industry companies are active members, most of such potential has already been realized, or is still in the process of becoming so. One of the most successful priority areas and partnerships within this strategy is the "smart building and home with timber chain", where companies have developed many new systems, materials, and products; progress has also been made in the field of wood science (SRIP, 2019).

\section{CONCLUSION \\ 5. ZAKLJUČAK}

The results of this study show that digitalization in the Slovenian wood industry is still at a relatively low level, but there are significant differences between companies. The size of a company is a factor that greatly influences the degree of digitalization, and the related firm plans for the near future. Awareness of the importance of digitalization and past experience of digitalization appear to be the most important reasons for further development of such technology and approaches within a company. It is also of particular importance to provide a digital infrastructure and implement the modern elements of a smart factory, develop smart products and raise employees' digital competencies. The latter is extremely important in terms of the efficient use of modern technologies and further development of companies in this field. For further development, the preparation of a digital strategy is a key document at both the national level (Republic of Slovenia, 2016) and at the level of companies, where the assistance of the state is very important. To this end, in 2019, companies are eligible to (co)-finance the preparation of digital strategies through vouchers (Digital Innovation Hub Slovenia, 2019), which eliminates one of the major obstacles that companies have highlighted in the research. With a clearly outlined strategy and its implementation, the situation with regard to the digitalization of wood-industry companies will also improve. In further research, it would be highly welcome to investigate in more detail the preparation of digital strategies in wood companies, and above all to compare their implementation with companies in other sectors.

\section{Acknowledgements - Zahvala}

The authors acknowledge the financial support from the Slovenian Research Agency (research core funding No. P4-0015 and P4-0059). 


\section{REFERENCES}

\section{LITERATURA}

1. Carretero Gomez, S.; Vuorikari, R.; Punie, Y., 2017: DigComp 2.1: The Digital Competence Framework for Citizens with eight proficiency levels and examples of use. Publications Office of the European Union. DOI: http:// dx.doi.org/10.2760/38842.

2. Cotteleer, M.; Sniderman, B., 2017: Forces of change: Industry 4.0. Deloitte Insights.

https://www2.deloitte.com/insights/us/en/focus/industry-4-0/overview.html?nc=1\#what is-industry-4 [25.6.2019)].

3. Herakovič, N., 2016: Nekateri tehnološki izzivi Industrije 4.0. Ventil, 22 (1): 10-16.

4. Hozdić, E., 2015: Smart factory for industry 4.0: A review. International Journal of Modern Manufacturing Technologies, 7 (1): 31.

5. Keidanren, 2016: Toward realization of the new economy and society. http://www.keidanren.or.jp/en/policy/2016/029_outline.pdf. [20.9.2019].

6. Kmet Zupančič, R., 2019: Development Report 2019. The Institute of Macroeconomic Analysis and Development of the Republic of Slovenia IMAD, Ljubljana. http://www. umar.gov.si/en/slovenias-development/ [10.10.2019].

7. Kropivšek, J.; Milavec, I.; Likar, B., 2017: Analiza poslovanja slovenske lesne panoge. Les/Wood, 66 (2): 47 56. https://doi.org/10.26614/les-wood.2017.v66n02a05.

8. Kropivšek, J., 2018: Konceptualni model digitalizacije izobraževanja: Primer visokošolskega izobraževanja v lesarstvu v Sloveniji. Les/Wood, 67 (2): 63-74. https://doi.org/10.26614/les-wood.2018.v67n02a06.

9. Kropivšek, J.; Perić, I.; Pirc Barčić, A.; Grošelj, P.; Motik, D.; Jošt, M., 2019: A Comparative Evaluation of Operational Efficiency of Wood Industry Using Data Envelopment Analysis and Malmquist Productivity Index: the Cases of Slovenia and Croatia. Drvna industrija, 70 (3): 287-298. https://doi.org/10.5552/drvind.2019.1937.

10. Lasi, H.; Fettke, P.; Kemper, H. G.; Feld, T.; Hoffmann, M., 2014: Industry 4.0. Business \& Information Systems Engineering, 6: 239-242. https://doi.org/10.1007/s12599-014-0334-4.

11. Lee, D., 2019: Ikea is introducing robotic furniture for people who live in small spaces.

https://www.theverge.com/2019/6/4/18652178/ikea-rognan-robot-murphy-bed-furniture-ori-living-democraticdesign-days [5. 8. 2019].

12. Movrin, P., 2017: Pametna tovarna na ključ za globalni trg. glas gospodarstva, november 2017, p. 45.

13. Panetta, K., 2018: Gartner Top 10 Strategic Technology Trends for 2019. Gartner. https://www.gartner.com/smarterwithgartner/gartner-top-10-strategic-technology-trends-for-2019/ [21.9.2019].

14. Paluš, H.; Parobek, J.; Liker, B., 2015: Trade Performance and Competitiveness of the Slovak Wood Processing Industry within the Visegrad Group Countries. Drvna industrija, 66 (3): 195-203. https://doi.org/10.5552/drind.2015.1431.

15. Paluš, H.; Parobek, J.; Dzian, M.; Šimo-Svrček, S.; Krahulcová, M., 2019: How companies in the wood supply chain perceive the forest certification. Acta Facultatis Xylologiae Zvolen, 61(1): 155-165. https://doi.org/10.17423/afx.2019.61.1.15.

16. Robbins, N. B.; Heiberger, R. M., 2011: Plotting Likert and other rating scales. In: Proceedings of the 2011 Joint Statistical Meeting, pp. 1058-1066.
17. Schmidt, R., Möhring, M.; Härting, R.-C.; Reichstein, C.; Neumaier, P.; Jozinović, P., 2015: Industry 4.0 - Potentials for Creating Smart Products: Empirical Research results. Business Information Systems, $18^{\text {th }}$ International Conference, BIS 2015, Poznań, Poland, pp. 16-27.

18. Zupan, G., 2018: Digitalni indeks slovenskih podjetij. Uporabna Informatika, 4: 11. https://uporabna-informatika.si/index.php/ui/article/view/5. [20.9.2019].

19. Xu, L. D., He, W.; Li, S., 2014: Internet of Things in Industries: A Survey. IEEE Transactions on Industrial Informatics, 10/4: pp. 2233-2243.

20. Xu, L. D.; Xu, E.; Li, L., 2018: Industry 4.0: state of the art and future trends. International Journal of Production Research, 56 (8): 1-22.

21. *** 1ka, 2019: Integrated support for survey process. https://www.1ka.si/d/sl [26.3.2019].

22. *** Alples, 2016: Alples partner v projektu "Akustično pametno pohištvo". https://www.alples.si/sl/stories/rc31partner-v-projektu-pametno-akusticno-pohistvo/ [27.7.2019].

23. *** Commission of the European Communities, 2019: Key Enabling Technologies. https://ec.europa.eu/growth/ industry/policy/key-enabling-technologies_en [20.9.2019.

24. *** Digital innovation hub Slovenia, 2019: Digitalna strategija. https://dihslovenia.si/smernice/digitalne-strategije/ [10.10.2019].

25. *** European Commission, 2016: The European Union explained: A digital single market in Europe - Bringing down barriers to unlock online opportunities. https://publications. europa.eu/en/publication-detail/-/publication/013683184e3d-11e6-89bd-01aa75ed71a1/language-en [20.9.2019].

26. *** European Commission, 2018: Smart specialization platform. http://s3platform.jrc.ec.europa.eu/ [20.9.2019].

27. *** European Commission, 2019: The Digital Economy and Society Index (DESI). URL: https://ec.europa.eu/ digital-single-market/en/desi [23.9.2019].

28. *** Republic of Slovenia, 2016: Digitalna Slovenija 2020 - Strategija razvoja informacijske družbe do leta 2020. https://www.gov.si/assets/ministrstva/MJU/DI/7df0f756bc/ Strategija-razvoja-ID.pdf [10.10.2019].

29. *** Republic of Slovenia, 2019: Izvajanje Slovenske strategije pametne specializacije. https://www.gov.si/ zbirke/projekti-in-programi/izvajanje-slovenske-strategije-pametne-specializacije/ [10.9.2019].

30. *** SRIP, 2019: Pametne stavbe in dom $\mathrm{z}$ lesno verigo. https://www.teces.si/sl/srip-psidl/fokusna-podrocjasrip\#Les [12.10.2019].

31. ***STA, 2015: Smart Specialisation Strategy Adopted. http://www.sloveniatimes.com/smart-specialisationstrategy-adopted [15.10.2019].

32. *** Statistical Office, Republic of Slovenia, 2018: The rate of digitization of enterprises with at least 10 persons employed in 2018. https://www.stat.si/StatWeb/en/News/ Index/7812 [14.10.2019].

\section{Corresponding address:}

\section{Assist. Prof. JOŽE KROPIVŠEK, PhD}

University of Ljubljana, Biotechnical Faculty

Department of Wood Science and Technology

Ljubljana, SLOVENIA

e-mail: joze.kropivsek@bf.uni-lj.si 